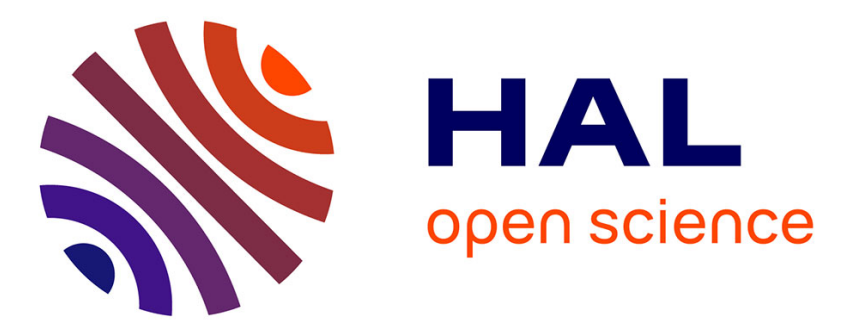

\title{
Interpretive structural modeling of risk sources in Virtual Organisation
}

\author{
Mohammad Jamal Alawamleh, Keith Popplewell
}

\section{To cite this version:}

Mohammad Jamal Alawamleh, Keith Popplewell. Interpretive structural modeling of risk sources in Virtual Organisation. International Journal of Production Research, 2011, pp.1. 10.1080/00207543.2010.519735 . hal-00660540

\section{HAL Id: hal-00660540 \\ https://hal.science/hal-00660540}

Submitted on 17 Jan 2012

HAL is a multi-disciplinary open access archive for the deposit and dissemination of scientific research documents, whether they are published or not. The documents may come from teaching and research institutions in France or abroad, or from public or private research centers.
L'archive ouverte pluridisciplinaire HAL, est destinée au dépôt et à la diffusion de documents scientifiques de niveau recherche, publiés ou non, émanant des établissements d'enseignement et de recherche français ou étrangers, des laboratoires publics ou privés. 


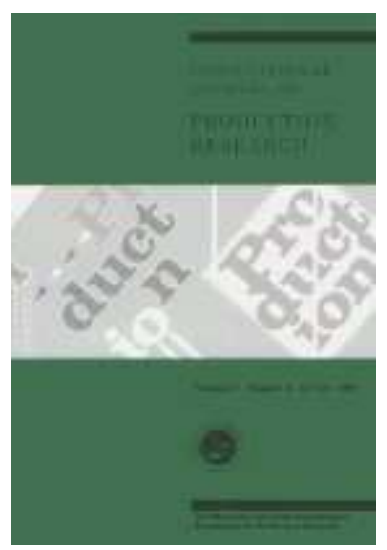

\section{Interpretive structural modeling of risk sources in Virtual Organisation}

\begin{tabular}{|r|l|}
\hline Journal: & International Journal of Production Research \\
\hline Manuscript ID: & TPRS-2010-IJPR-0130.R1 \\
\hline Manuscript Type: & Original Manuscript \\
\hline $\begin{array}{r}\text { Date Submitted by the } \\
\text { Author: }\end{array}$ & 20-Jul-2010 \\
\hline Komplete List of Authors: & $\begin{array}{l}\text { Alawamleh, Mohammad; Coventry university } \\
\text { Popplewell, Keith; Coventry University, Engineering Manufacture } \\
\text { and Management }\end{array}$ \\
\hline Keywords (user): & $\begin{array}{l}\text { VIRTUAL MANUFACTURING, VIRTUAL ENTERPRISE, } \\
\text { COLLABORATIVE MANUFACTURING, RISK MANAGEMENT }\end{array}$ \\
\hline \multicolumn{2}{|l}{} \\
\hline
\end{tabular}

\section{SCHOLARONE ${ }^{m}$ Manuscripts}




\title{
Interpretive structural modeling of risk sources in Virtual Organisation
}

\author{
Mohammad Alawamleh, Keith Popplewell \\ Engineering Manufacture and Management, Coventry University, Coventry, UK
}

\author{
Coventry University, Priory Street, Coventry CV1 5FB, United Kingdom \\ \{awamlehm, K.Popplewell\} @uni.coventry.ac.uk
}

\begin{abstract}
Speedier network decision making together with shorter time to bring items to market together with lower network operating costs all result from enhanced knowledge sharing. In addition re-use of enterprise and network knowledge resulting from improved capture means that any risk of repeating earlier project work is limited, repetition of past mistakes is reduced. Decisions are made with greater awareness of any risks involved and therefore there is likely to be a reduction in costs arising from faulty decisions and failed collaborations. While there are many advantages attaching to the use of virtual organizations (VOs) there are also challenges, including risks that have become apparent through undertaking a review of the literature. In total 13 sources of risk were found stemming from the network related risks in a VO, where the emphasis of the study was placed. This paper contains a thorough study that will identify these threats as well as gaining a sound understanding of them by examining them one by one as they have been identified by the literature and previous studies. Subsequently, their relative importance will be analysed through the use of Structural Modeling (ISM) using information gathered in a questionnaire.
\end{abstract}

Keywords: virtual organisation; VO; risk; SME; interpretive structural modelling; ISM

\section{$1 \quad$ Introduction}

Collaboration between enterprises is vital if businesses are to meet their objectives. Doing business world-wide has become crucial to the survival of some enterprises while for others the vital element is focusing locally. It is necessary for all enterprises, whatever their size, to come to corporate agreements with other enterprises and this is particularly important for small and medium sized enterprises (SMEs) who in order to increase their own added value need to operate together with others within the market. In today's market, whether or not an enterprise is successful will often be largely dependant upon whether it is able to interoperate smoothly with others.

The environment within which SME's have to function in the 21 st century is one that is increasingly competitive and dynamic and therefore, simply to cope in such a situation, SMEs have to seek methods to employ: one of these is to group together within a VO. It is, however, not easy to become part of a VO and there are risks to be dealt with throughout the whole process from the initial formation of such a group through to the point where it dissolves. In order that the challenges can be met successfully, it is important that enterprises should be helped to both recognise the risks and then surmount them.

Collaboration is necessary in order for enterprises to compete and it is also necessary for them to operate with as much speed and flexibility as possible so that ideas and proposals can become initiatives with the capacity to generate new revenue.

As is the case in the supply chain, the risks associated with VOs have multiple sources and Juttner et al. (2002) have suggested that the sources of risk as they affect supply chains should be categorised into three areas, those being risks external to the supply chain, risks internal to the supply chain and those that are network related. Such risks as natural risks, political and social risks and risks connected to the industry market would be categorised as external risks while internal risk sources are likely to be associated with labour problems such as strikes, or production problems such as machine failure, as well as problems with IT systems and network related risks stemming from the relationships between the supply chain, 
also been by Blackhurst et al. (2004) as a risk that is different in kind but that has a direct relationship with collaboration.

While the risk sources that are internal or external are essentially similar for supply chain and virtual organisation, the network related risks have a different source as a result of the different relations between the SC and the VO partners. Those network risks that relate to any collaboration do not depend solely on the enterprise goals and objectives. A dyadic type of assessment is necessary as a result of the sharing of responsibilities and the changing nature of the relationships involved if these situations are to be actively managed in relation to network related risks, since the identification of risk becomes more complex as a result of the interdependency of enterprises (Hallikas et al., 2004).

The aim of this study is to explore various risk sources in the VO, to establish relationships among the sources through ISM methodology and to classify these sources depending upon their driving and dependence power using indirect relationship MICMAC analysis ISM is a well-established methodology for identifying and summarising the relationships among specific elements which define a problem or an issue (Sage, 1977; Warnfiled, 2005). The proposed model provides a useful tool for SMEs to focus on those risk sources that are most important for effective risk management in VOs. Understanding the risk sources and their relationships will help organisations address them or at least understand so they can plan for them if and when they occur.

Based on literature, risk sources that affect VO directly and indirectly, are identified. A survey was prepared and administered to test the validity of each of these sources as well as to identify additional sources affecting VO. In this paper the literature related to the risk sources in the network level of the VOs will first be examined, and then the ISM methodology will be explained before mapping the relation between risk sources using ISM. Finally results of MICMAC (Duperrin and Godet, 1973) analysis of the sources will be presented in section 4 .

\section{Identification of risk sources in the Virtual Organisation}

A number of authors who have researched and written about this area have identified where risk arises in VO. Comprehensive examination of the literature identified 13 sources of risk and impediments which can be possible causes of failure to hit targets in the areas of delivery time and cost and quality and in some instances where the collaboration has collapsed completely. A brief discussion of each of these sources as identified in supply chain management literature and related literature follows and will be the basis of the subsequent survey and analysis.

\subsection{Lack of trust}

This was the most frequently discussed VO risk. The degree of trust that exists between partners relates to how much partners believe in the honesty, generosity and overall competence of the others. Where there is no trust between partners problems arise; for instance they become unwilling to pass on sensitive information, find it difficult to agree about how finances should be managed. In short they do not work to promote VO collaboration.

Trust and commitment are crucial to collaboration and for cooperation over a period of time together with a preparedness to share risks (Sahay and Maini, 2002). The more the trust between SC partners, the more the commitment (Mistry, 2005). However a lack of trust is one of main contributors to SC risks (Sinha et al., 2004). According to Lengnick-Hall 
(1998) where trust has grown out of good communication, it leads to resources that themselves can give a competitive edge. Trust assumes that those party to an agreement will not act opportunistically even when they are tempted by possible short-term advantage to themselves (Chiles and McMackin, 1996) and it can make a marked contribution to the stability of an organisation in the long term and to its network (Speckman and Davis, 2004).

For collaboration to work all partners must work together to solve problems and this demands that there is powerful mutual trust and the commitment to expend time and effort (Camarinha-Matos and Afsarnesh, 2007). Where risk arises from the VO being exposed to partners' opportunistic behaviour, or else to any uncertainty and ambiguity or only partial information, trust becomes vital in order to reduce it. However trust itself invites risk since it exposes those who trust to the opportunistic behaviour of others (Panteli and Sockalingham, 2005). There is an important constructive relationship between trust and conflict resolution in any inter-organisational arrangement (Twomey, 1995) and trust enables benefit to be gained from conflict since conflict can often lead to innovation (Pascale, 1994).

Ryutor et al. (2007) consider that the establishment of trust between VO collaborators is essential to successful joint performance and presents a conceptual framework dealing with key concepts that will initiate trust between VO collaborators in on-demand VO. Lewicki et al. (1998); Zaher et al.(1998) argue that without trust it is not possible for there to be social, economic or political dealings since one party must initiate the contact making the unspoken assumption that there is likely to be a positive response from the other party. Adobre (2005) showed that the trust building in partnership maybe sort of self fulfilling prophecy in which initial expectation positively impact behaviour and trust building, where there may be some optimal level of expectation. In his study he found that both too low and too high an expectation was counterproductive to trust building.

\subsection{Inadequate collaboration agreement}

A lack of clarity in the agreement into which partners enter is one of the circumstances that can lead to insufficient collaboration. According to Camarinha-Matos and Afsarmanesh, 2007; Westphal et al., 2007; Bullinger, 2003 where any definition dealing with objectives is weak, together with the strategies and basic conditions and where expectations are poorly managed, and contracts perceived as inadequate or unfair, there may well be risk of failure.

The moral risk before the VO is set up was discussed by You and Yu (2006), when members may be able to reduce the extent of knowledge sharing though setting up a contract, with Quirchmayr et al. (2002) describing contracts for negotiation where a legally binding contract may have to be signed by each partner requiring them to accept the process, protocols, and constitution of the VO. Both risks and rewards must be shared among SC members according to Mentzer (2001) if Supply Chain Management (SCM) is to work efficiently since all members must respond to the same incentives which results in a fair distribution across the network of the risks as well as the costs and rewards of the business (Narayanan and Raman, 2004). Tsay (1999) describes the sharing of revenue as a type of SC contract that facilitates the sharing of risks also.

The degree of risk and benefit sharing differs with the type of the collaboration. Joint ownership is often the mechanism with risks arising from joint venture or strategic alliance (Zheng et al., 1998). Methods of incentive for the collaborating parties may be through the use of obligation contracting, schemes for profit sharing and shared property rights as well as ownership control. Where collaborations are not so formal the nature of sharing risks and benefits may not be so clear, therefore lasting commitment may depend on agreements being made so that sensitive information, knowledge and competencies can be shared. Where there is trust there will be less reluctance to share sensitive information since the perception of risk is reduced. This in turns means that complex contracts are less likely to be seen as necessary 
to protect interests and there is trust in the decision making across the group since it is believed that all perspectives will be considered (Chiles and Mcmakin, 1996).

\subsection{Ontology differences}

Ontology is a philosophical system that is concerned with the nature of being. Gruber (1995) defines ontology as "a formal, explicit specification of a shared conceptualisation". Problems in this area of ontology crop up when there are two different words with the same meaning or even where one word means different things as it used by different partners.

According to Plisson et al. (2007) ontologies can be said to offer an economical and unambiguous way of representing knowledge so that it can be jointly understood and therefore provide a basis for sharing. However, before terminology can be shared, there needs to be consensus between partners as to which terms they will use when collaborating where problems have previously arisen because ontologies have not been held in common between organisations working together (Camarinha-Matos, 2002).

What ontology can do is provide a means of sharing knowledge where there is an understanding of concepts and relationships within a certain area and communication between those involved in this area where the fundamental ontology is one acting as a glossary for a limited vocabulary which are the agreed terms used within a specific area. Where problems occur as a result of differing ontologies there may be disagreements in relation to both the formation and the processes of collaboration which will add to the risks in the VO.

\subsection{Heterogeneity of partners}

Heterogeneity means the differences that exist between partners in terms of incompatible hardware and operating systems, differences in language and the recording of data and in the meaning of the terms that are used. (Camarinha-Matos and Afsarmanesh, 2007; Sari et al., 2007) have all referred to this heterogeneity between possible partners as it exists in information technology infrastructures, working methods and business practice, as a possible obstacle to the VO operation.

Where there is poor technological infrastructure this makes it difficult to put in place knowledge management (Singh and Kant, 2008). Jung (2008) saw variations between these categories as an impediment to the progress of efficient cooperation since the semantics of the information from various entities may differ. These variations occur because of the variations in terminology with a number of synonyms and antonyms in use but also and more importantly because of differences within the databases derived from the knowledge structures (Hull, 1997) and the ontology (Jung, 2005).

\subsection{Structure and design}

VO's dynamic structure creates problems since it is not possible to co-ordinate comparable activities because responsibilities are not adequately shared out and it may not be clear what the tasks and the rules are nor who is in overall charge, nor how far any control extends, and where a phase leader is unable to manage the other partners and does not have the right to make decisions the whole network is affected. Elements of structure and design include central planning or decentralisation, the extent of any specific control and specialisation and how labour is divided (Zhang and Dilts, 2004).

According to Camarinha-Matos and Afsarmanesh (2007) where the infrastructure does not offer the opportunity for joint collaboration, this proves an obstacle to a VO. Control that is weak or ineffective can occur outside the project and can spring from interorganisational networking in a way that resembles that in which (Finch, 2004; 
Bandyopadhyay, et al., 1999) found that where control over suppliers and customers was weak within the grouping, risks could occur.

\subsection{Loss of communication}

The variation inherent in VO and the changes in structure can lead to less communication and here an inverse relationship comes into play since the less the communication the more the uncertainty.

According to Grabowski and Roberts (1998) while communication is fundamental to any organisation it is of even more vital importance within VOs. Any communication in a virtual form must respond to specific customer demand with speed (David and Malone, 1992). Others (Camarinha-Matos and Afsarmanesh, 2007; Westphal et al., 2007; Bamford et al., 2004; Bullinger, 2003; Gunasekaran et al., 2008) have all seen failing communication as an obstacle within VOs and where this happens, failure could follow.

It is likely that a more trusting relationship between collaborators will be the result of better communication; the crucial aspect is to go beyond technology to establish trust over key issues with a free flow of information and where the most critical issues can be raised with the partners being at ease even when exchanging sensitive information. Partners must understand that communication has to be about commitment levels rather than about technology (Speckman and Davis, 2004).

\subsection{Culture differences}

There may be several cultures within a VO and this may lead to lack of alignment between processes and inaccurate communication impacting on the sharing of information (Grabowski and Roberts, 1998; Chen and Fang; Prefontain, 2003; Camarinha-Matos and Afsarmanesh; 2007).

The fundamental values and beliefs of any culture, together with value norms and the customs underpinning the behaviour of people within an organization, define it (Singh and Kant, 2008; Lemken et al., 2000). However, where there is no over-arching culture in any organisation this has a negative impact on the successful management of knowledge (Chase, 1997).

You et al. (2006) focus on members of a VO, saying the centre of any enterprise resides in its values and they therefore use such terms as staff value, faith and behaviour in relation to this so and those joining a VO undertaking come from different enterprises and therefore shared knowledge will be in short supply. It may be that those who come together to form a VO are culturally dissimilar and they may never before have worked as a partnership and so they will have little experience in common. This is an important issue since enterprises have become increasingly transactional and virtual partnerships have been made easier by technological advances and this brings with it different cultural backgrounds and different uses of language as well as values, all of which impact on the dispersed team function (Crossman and Kelley, 2004).

\subsection{Bidding for several Virtual Organisations at the same time}

Some partners may choose to be active in several VOs simultaneously when they do not have the capacity to cope with this. Risk then occurs when one partner wins two or more VO bids and his capacity as a partner, either in terms of resources or staff, is not sufficient to undertake the tasks involved in more than one VO. Although this risk occurs, there is as yet little discussion of it in the literature and it has not been much researched. Even in Camarinha-Matos (2002) the vagueness is there when he discusses only the other causes of risk in a VO. Nguyen et al. (2005) discuss only resource management and bidding strategies as possibly problematic in a VO. 


\subsection{Lack of information sharing}

It is crucial for information to be shared where there is decreasing information visibility in the VO so that there is less risk including that of catalogue non-availability that includes up to date and standardised profiles of organizations. However, the availability of more information sharing can cause loss of IPR. In order for knowledge sharing to be accepted, a VO must have established values relating to sharing and collaboration as part of their fundamental ethos. Some may feel that they have an advantage because they possess knowledge that others do not and this causes a refusal to share knowledge with others out of a desire to protect their own interests (You et al., 2006).

Networks must share information because where it is lacking the result may be panic, confused behaviour and increased costs (Childerhouse et al., 2003). It is agreed currently by models for SCM that sharing business information is vital, connecting SC completely together (Zhenxin et al., 2001; Yu et al., 2001). According to Rahman (2004) it is felt that there is a risk involved in sharing with other members such sensitive information as inventory levels and production schedules. Information sharing should be subject to choosing those with whom the information will be shared, what type of information it will be and of what quality.

Efficient network coordination depends upon information sharing, with a number of studies finding that it impacts significantly on network performance and, in particular, is able to reduce the bullwhip effect. Information sharing leads to better operational decision making within enterprises which leads to more efficient use of resources and lower costs (Lee et al., 1997; Yu et al., 2001).

\subsection{Lack of top management commitment}

Risk is increased where a weak part is played by top level management at particular points in VO formation or operations where crucial decisions are made (Camarinha-Matos and Afsarmanesh, 2007; Westphall et al., 2007; Bamford et al., 2004; Bullinger, 2003).

According to Kanter (1997) there is a risk that low commitment to a partnership will lead to a failure to meet objectives. The role of top management is critical with it being responsible for all activities at every level of an organisation, for the technological infrastructure and for decision making in order that there will be efficient creation of knowledge together with sharing and use (Brand, 1998).

\subsection{Lack of knowledge about risks}

Where there is no knowledge of the risks that may occur there is an increased likelihood that these risks will occur and also have a greater impact.

According to Hallikas et al. (2004) where there is a greater understanding of the risks that may occur in an SC there is likely to be improved decision making and lower risk to each enterprise involved as well as to the whole undertaking. It is possible to categorise the many different forms of SC risks in terms of how their occurrence would affect a business and its environment (Harland et al., 2003). With an understanding of the range of SC risks and how they interact can come a response from the enterprise creating balanced and efficient risk reduction strategies (Chopra and Sodhi, 2004). It is important for organisations to come collectively to an understanding of the risks they may face (Jüttner, 2005).

Risk analysis has the means to detect risk in a process (Sinha et al., 2004) and this enables a secure environment in which decisions can be taken so that there is a continuous assessment of the possibility of risk; it is possible to decide which are serious and then take appropriate action to deal with them (Shtub et al., 1994). 


\subsection{Wrong partner/s selection}

According to Camarinha-Matos and Afsarmanesh, 2007; Westphall et al., 2007; Bamford et al., 2004; Bullinger, 2003 such things as objectives, strategies, core competencies and capabilities that are irreconcilable cannot be complementary. While Sari et al. (2007) considered insufficient information about partners to be an obstacle to the VO selection, others including (Grabowiski and Roberts (1998); Chen and Fang (2002)) thought that a range of interests increased the risks to a VO.

According to Wilmont and Hocker (2001) conflict can be viewed as the manifestation of a struggle between a minimum of two parties who are mutually dependant but who have divergent goals, with limited rewards, and who have other parties placing obstacles in the way of the achievement of their goals. Organisational conflict manifests itself through conflicting relationships or affective conflict, cognitive or task conflict, and conflict over process. Furthermore, Wong (2009) acknowledged that conflicts between partners is one of the obstacles of virtual networks, where Susman et al. (2003) suggested that conflicts could appear due to the polarisation of functions as between marketing and designers where they want customised product, whereas production department wants to manufacture standardised products.

\subsection{Geographic location}

Risk may be increased by geographic locations with there being a direct correlation between distance and risk. Some locations throw up more problems because of, for instance, political and legal difficulties (Ritche and Brindly, 2002; Dewitt et al., 2006). Prater et al. (2001) looked at the size of any geographic area that a network covered, what political areas it encompassed and which borders were crossed, considering these all to be elements contributing to the partners' exposure to risk.

Porter (1998) observed that geographic distance gives rise to complications and to an increase in logistic cost. Also Grabowski and Roberts (1998), Chen and Fang (2002) considered that there was increased risk as a result of geographic distance.

\section{Interpretive Structural Modeling (ISM)}

ISM is one of the Interactive Management methods which assist research groups in dealing with complex issues (Warnfield, 1974; 1990; 2005). ISM transforms unclear, poorly articulated mental models of a system into visible well defined, hierarchal models. It is a well known methodology for identifying and summarising relationships among specific elements, which define an issue or a problem, and provide a means by which order can be imposed on the complexity of such elements (Mandal and Deshmukh 1994). Thus, a set of different and directly related elements are structured into a comprehensive systematic model. ISM is primarily intended as a group learning process, but individuals may also apply it (Ravi and Shankar, 2005, Faisal et al., 2007). Any methodology for dealing with complex issues, must, therefore, be able to break complexity down into manageable chunks of information so that the human mind can deal with it. ISM tries to do this, by enabling an individual or a group to focus on the interrelations between two elements in an issue at a time, without losing sight of the properties of the whole (Waller, 1975).

From the risk sources which have been identified earlier and the potential impact of failure to meet delivery time, cost and quality targets or total failure for the collaboration, a questionnaire was developed using ISM methodology to determine underlying relations among these sources. ISM is a process that helps people to structure their collective knowledge and to model interrelationships in a way that enhances our ability to understand 
complexity. In other words, it helps to identify structure within a system of related elements and provide the opportunity to analyse it from several viewpoints.

Steps involved in ISM methodology which are summarised in (Figure 1) are as follows:

Insert Figure 1

1) Identification of the elements that are relevant to the problem or issue.

2) From the elements identified in the first step, establishing the contextual relationship among them. This represents the relationship indicating whether or not one element leads to another.

3) Developing a structural self-interaction matrix (SSIM) of sources which indicates a pair-wise relationship between sources of the system under consideration.

4) Developing a reachability matrix from the SSIM, and checking the matrix for transitivity. Transitivity of the contextual relation is basic assumption in ISM which states that if element $\mathrm{A}$ is related to element $\mathrm{B}$, and $\mathrm{B}$ is related to $\mathrm{C}$, then $\mathrm{A}$ is necessarily related to C. The SSIM format is transformed in the format of the reachability matrix by transforming the information in each entry of the SSIM into 1s and $0 \mathrm{~s}$ in the reachability matrix.

5) The reachability matrix obtained in the fourth step is partitioned into different levels.

6) Based on the relationships in the reachability matrix, removal of the transitive links and drawing a directed graph.

7) Constructing the ISM model by replacing element nodes with statements.

8) The ISM model developed in the seventh step is reviewed to check for conceptual inconsistency, and to make the necessary modifications.

These steps in more details below:

\subsection{Survey}

A questionnaire was presented to the respondents of the survey and respondents were asked to complete it. We sent the questionnaire via the INTEROP-VLab mailing list which contains 224 members mainly experts in the interoperability and collaborations issues from both industry and academia. INTEROP-VLab is the "International Virtual Laboratory or Enterprise Interoperability", officially created as a non profit organisation under Belgian law (interop-vlab.eu, 2009). 45 experts from the INTEROP-VLab members participated in the study. Using the research data collected from these respondents and following the steps described above, the ISM directional graph is developed.

Insert Table 1

Table 1 is a summary of the questionnaire of the survey. The questionnaire was presented to the respondents to the survey, and respondents were asked to answer a total of 78 questions, with each cell in the upper right cells representing a question. Respondents were asked to compare the column statement with the row statement for each cell and to choose a value from the set $(\mathrm{V}, \mathrm{A}, \mathrm{X}$, or $\mathrm{O})$ to represent their perception of direct relationship between two sources at each time. $\mathrm{V}$ represent relation when the first source $\mathrm{i}$ influence the second source $\mathrm{j}$, but not in the reverse direction, $A$ for the relation when the second source $\mathrm{j}$ influence the first source $i$, but not in the reverse direction, $X$ represent interrelation between both sources (both directions), finally $\mathrm{O}$ represent that both sources ( $\mathrm{i}$ and $\mathrm{j}$ ) are unrelated.

The symbolic values ( $\mathrm{V}, \mathrm{A}, \mathrm{X}$, or $\mathrm{O}$ ) are translated into binary values (section 3.3 ) to develop a directional graph (figure 2). The detailed ISM methodology used to develop the 
directional graph is explained below. The contextual relation is established based on a pairwise assessment of all the thirteen risk sources as shown in (Table 2), and the majority (70\%) of the respondents agreeing to a specific relation between any two sources. With the use of this methodology, we can identify the direct and indirect relationships between risk sources in the VO.

\subsection{The Structural self-interaction matrix (SSIM)}

ISM methodology suggests the use of the expert opinions in developing the contextual relationship among the risk sources. The approach relies on academic experts or managerial background from the INTEROP-VLab who answered our questionnaire with their opinions to arrive at the structure and relationship of the risk sources.

Keeping in mind the contextual relationship for each source, the existence of a relationship between any two sources ( $i$ and $j$ ) and the associated direction of the relation are questioned. Based on the contextual relationships the SSIM (Table2) is developed for the 13 sources identified for the risk in the VO.

Insert Table 2

\subsection{Reachability matrix}

The SSIM (Table 2) is transformed into a binary matrix, called the initial reachability matrix by substituting $\mathrm{V}, \mathrm{A}, \mathrm{X}$ and $\mathrm{O}$ by 1 and 0 as per the case. The rules for the substitution of $1 \mathrm{~s}$ and 0 s are as follows:

- If the $(i, j)$ entry in the SSIM is $V$, then the $(i, j)$ entry in the reachability matrix becomes 1 and the $(j, i)$ entry becomes 0 .

- If the $(i, j)$ entry in the SSIM is A, then the $(i, j)$ entry in the reachability matrix becomes 0 and the $(\mathrm{j}, \mathrm{i})$ entry becomes 1 .

- If the $(i, j)$ entry in the SSIM is $X$, then the $(i, j)$ entry in the reachability matrix becomes 1 and the $(\mathrm{j}, \mathrm{i})$ entry also becomes 1 .

- If the $(i, j)$ entry in the SSIM is $\mathrm{O}$, then the $(i, j)$ entry in the reachability matrix becomes 0 and the $(j, i)$ entry also becomes 0 .

After incorporating the transitivities as described in step 4 of the ISM methodology, the final reachability matrix is shown in table 3.

Insert Table 3

In this table, the driving power of a particular source is the total number of sources (including itself) that it influences. The dependences is the total number of sources (including itself) that it may help influencing its growth. These driving power and dependency values will be used in classification of risk sources (MICMAC analysis).

\subsection{Level partitions}

The reachability and antecedent set (Warfield, 1974) for each source are obtained from final reachability matrix. The reachability set for a particular source consists of the source itself and the other sources, which it influences. The antecedent set consists of the source itself and the other sources, which may influence it. Subsequently, the common sources of the reachability and antecedent sets from the intersection sets are the same as assigned as the toplevel element in the ISM hierarchy as it would not help achieve any other source above their own level. After the identification of the top-level source, it is discarded from further hierarchical analysis (i.e. removing that source from all the different sets). For example, as 
seen in Table 4, 'Wrong partner/s selection' (Source 12) is found at level 1 due to similar reachability and intersection sets. Thus, it would be positioned at the top of the ISM hierarchy. Source 12 is then removed from all different sets for further analysis, as its level has been obtained This iteration is repeated till the levels of each source are found out (Tables 4 to 10). The identified levels aids in building the digraph and the final model of ISM.

Insert Tables (4-10)

\subsection{Formation of ISM-based model}

The structural model (Figure 2) is generated from the final reachability matrix and the digraph is drawn. Removing the transitivities as described in the ISM methodology, the digraph is finally converted into the ISM. The contextual relationship in this structure was "leads to". This implies that each arrow is read as "leads to".

Insert Figure 2

\section{Classification of the risk sources (MICMAC analysis)}

MICMAC was developed by Duperrin and Godet (1973) to study the diffusion of impacts through reaction paths and loops for developing hierarchies for members of an element set. MICMAC analysis can be used to identify and analyse the elements in a complicated system (Warfield, 1990). Generally, the elements will be classified into four clusters of autonomous, dependent, linkage and independent (driver) sources according to the driving power and dependencies of all the elements (Ravi and Shankar, 2005).

The objective of the MICMAC analysis is to analyse the driving power and the dependence of the elements (Mandal and Deshmukh, 1994, Faisal et. al., 2006). In this analysis, the risk sources described earlier are classified into four clusters. The first cluster consists of the "autonomous sources" that have weak driving power and weak dependence. These sources are relatively disconnected from the system, with which they have only few links, which may not be strong. In our case there are no sources in the autonomous cluster which indicates no sources can be considered as disconnected from the whole system and the management has to pay attention to all the identified risk sources in VO.

The "dependent sources" constitute the second cluster which has weak driving power but strong dependence. We have six sources in this cluster; Lack of top management commitment, lack of information sharing, lack of trust, bidding for several VO at the same time, lack of knowledge about risks and wrong partner/s selection. It forms the top level in the ISM hierarchy. It represents the source that is the resultant action for risks in VO. Its strong dependence indicates that it requires all the other risks to come together so as to increase them in VO risks. The third cluster has the "linkage sources" that have strong driving power and strong dependence. These sources are unstable due to the fact that any change occurring to them will have an effect on others and also a feedback on themselves. Just one of the risk sources in this cluster which is loss of communication is influenced by lower level sources and in turn impacts other sources in the model. The fourth cluster includes the "independent sources" having strong driving power but weak dependence. Six risk sources are in this cluster: geographic location, culture differences, ontology differences, heterogeneity of partners, inadequate collaboration agreement and structure and design. These six sources play a key role in risks in a VO.

The objective behind this classification of the risk sources is to analyse the driver power and dependency of sources (Jharkharia and Shankar, 2005). In general, higher sources driver power means that a large number of sources could be easily removed by its removal. 
Higher dependence values for sources require a large set of sources to be addressed before its removal and a more likely success in the implementation of VO risks. The classification of risk sources within the four clusters helps identify the difficulty removal potential of the risk sources.

The driving power and the dependence of each of these sources are shown in (Table 4). In this table, an entry of ' 1 ' along the columns and rows indicates the dependence and driving power, respectively. Subsequently, the driver power-dependence diagram is constructed which is shown in (Figure 3).

\section{Insert Figure 3}

\section{Discussion}

The objective of the ISM model in this research is to develop a hierarchy of risk sources that would help mitigate risks in VO. The model developed in this paper provides the opportunity to understand the network risk sources in VOs. It is clear that awareness about risk sources is very important as it would lead to efforts being undertaken to minimise these risks. The task of management is to place high priority on those sources that form the base of ISM model because it is they who would drive other sources. The significant features of ISM methodology can be summarised as:

- it provides an understanding of the relationships among the risk sources in the network level in the VO;

- classification of sources under autonomous, dependent, linkage and independent categories;

- it attempts to develop a new understanding of risks sources due to the SMEs' collaboration.

- Suggested methodology would help the SMEs to develop strategies to mitigate risks.

\section{Conclusion and future work}

Based on the literature review and expert opinions, a number of risk sources in the VO which may cause to have negative effects on the time, cost, quality or total failure for the collaboration have been identified. The 13 risk sources identified in this research have significant overlaps and relationships that are sometimes difficult to see. A more complete understanding of these risks sources and their relationships, through logical structure, will help enterprises to take better decision as to whether to participate in a particular VO. For this reason we have sought to present an application of the ISM process to the data collected on relationships between the risk sources.

ISM can only act as a tool for imposing order and directions on the complexity of relationships among the variables. It does not suggest any relative weights associated with the variables (Kannan et al., 2008). Even so, this model can be applied with other approaches such as the Analytical Network Process (ANP) (Saaty, 2001), which requires a decision structure to help determine the weights of each risk source. Simulation and systems dynamics modeling may also be used to help identify how risk sources in VO will influence it and its performance results.

We therefore conclude that there is a sufficient body of expert opinion relating to the risks arising in the creation and operation of VOs to support a meaningful analysis leading to enhanced understanding of the relationships between sources of risks and the relative significance (weights) of these risks. This can inform an SME (or indeed larger enterprise) 
decision to participate in a $\mathrm{VO}$, as well as operational decision-making once a $\mathrm{VO}$ is established. For this reason we consider that deeper analysis may yield further valuable insights.

In the future work we can quantify the risks in VO. This depends upon the degree of inheritance of various variables and the amount of interaction that is possible by using Delphi, AHP, ANP, SEM or fuzzy logic. While using graph theory and matrix methods the interaction among the variables can be easily analysed and transformed into mathematical equation. The graph theory and matrix methods consist of the diagraph representation, the matrix representation and the permanent matrix representation. The digraph is the visual representation of the sources and their interdependencies. The matrix converts the digraph into mathematical form and the permanent function is a mathematical representation that helps to determine a risk index. This would enable SMEs to understand the contribution of various risk sources and put their efforts into mitigating these risks.

Furthermore, fuzzy ISM, a step ahead of binary ISM, may also be carried out. While only the existence of relations is considered between elements in the ISM, the strength of relations is additionally considered in FISM. The strength of relation can be quantified using 0-1 scale. Additional future research could include broadening the inputs and validation with more practitioners and by evaluating an actual set of risk sources in a real case study with an experimental approach to determine if the model's relationships are influenced as hypothesised on expert opinions.

In addition to the above directions identified already, Structural Equation Modelling (SEM) has the capability of testing the validity of such hypothetical models. Therefore, it may be applied in future research to test the validity of this model. SEM models can be tested using LISREL or AMOS software. SEM models also provide the path coefficients for the different relationships among the sources. This would complement the MICMAC analysis to further strengthen the understanding about the more important relationships requiring maximum attention.

\section{References}

Adobor, H. (2005) 'Trust as Sensemaking: The Microdynamics of Trust in Interfirm Alliances.' Journal of Business Research 58, 330-337

BAMFORD, J., ERNEST, D. \& FUBINI, D. G. (2004) Launching a World-Class Joint Venture. Harvard Business Review 82, 90-100.

BANDYOPADHYAY, K., MYKYTYN, P. P. \& MYKYTYN, K. (1999) A framework for integrated risk management in information technology. Management Decision, 37, 437-445.

BLACKHURST, J., WU, T. \& O'GRADY, P. (2004) Network-based approach to modelling uncertainty in a supply chain. International Journal of Production Research, 42, $1639-1658.00$

BRAND, A. (1998) Knowledge management and innovation Journal of Knowledge Management, 2, 17-22.

BULLINGER, H.-J. (2003) Collaborative development - potentials of success in development networks. Supply Chain Management, 2, 31.

CAMARINHA-MATOS, L. M. (2002) Virtual Organizations in Manufacturing: Trends and challenges. Proceedings of Flexible Automation and Intelligent Manufacturing. Munich, 1036-1054.

CAMARINHA-MATOS, L. M. \& AFSARMANESH, H. (2007) A framework for virtual organization creation in a breeding environment. Annual Reviews in Control, 31, 119- 
135.

CHASE, R. L. (1997) The knowledge-based organization: an international survey. Journal of Knowledge Management, 1, 38-49.

CHEN, J. \& FENG, W. D. (2002) Formation and Management of Virtual Enterprises Tsinghua University Press.

CHILDERHOUSE, P., HERMIZ, R., MASON-JONES, R., POPP, A. \& TOWILL, D. R. (2003) Information flow in automotive supply chains - identifying and learning to overcome barriers to change. Industrial Management \& Data Systems, 103, 491-502.

CHILES, T. H. \& MCMAKIN, J. F. (1996) Integrating variable risk preferences, trust, and transaction cost economics. Academy of Management Review, 21, 73-99.

CHOPRA, S. \& SODHI, M. S. (2004) Managing risk to avoid supply chain breakdown. Sloan Management Review, Fall, 53-61.

CROSSMAN, A. \& LEE-KELLEY, L. (2004) Trust, commitment and team-working: the paradox of the virtual organization. Global Networks, 4, 375-390.

DAVID, W. H. \& MALONE, M. S. (1992) The Virtual Corporation, New York, NY, HarperCollins Publishers.

DEWITT, T., GIUNIPERO, L. C. \& MELTON, H. L. (2006) Clusters and supply chain management: the Amish experience. International Journal of Physical Distribution \& Logistics Management, 36, 289-308.

DUPERRIN, J. C., AND GODET, M. (1973) Methode De Hierar Chization Des Elements D'um System. Rapport Economique De CEA, 45-51.

FAISAL, M., BANWET, D. K. \& SHANKAR, R. (2007) Quantification of risk mitigation environment of supply chains using graph theory and matrix methods. European Journal of Industrial Engineering, 1, 22-39.

FINCH, P. (2004) Risk Management Consultant with AEA Technology, Warrington, UK. Supply Chain Management: An International Journal, 9, 183-196.

GRABOWSKI, M. \& ROBERTS, K. H. (1998) Risk Mitigation in Virtual Organizations. Organization Science, 10.

GROVER, S. L. (2005) Trust and distrust in organizations: dilemmas and approaches. Personnel Review 34, 57-509.

GRUBER, T. (1995) Toward principles for the design of ontologies used for knowledge sharing. International Journal of Human Computer Studies., 43, 907-928.

GUNASEKARAN, A., LAI, K.-H. \& CHENG, T. C. E. (2008) Responsive supply chain: A competitive strategy in a networked economy. Omega, 36, 549-564.

HALLIKAS, J., KARVONEN, I., PULKKINEN, U., VIROLAINEN, V. M. \& TUOMINEN, M. (2004) Risk management processes in supplier networks". International Journal of Production Economics, 90, 47-58.

HARLAND, C., BRENCHLEY, R. \& WALKER, H. (2003) Risk in supply networks. Journal of Purchasing \& Supply Management, 9, 51-62.

HULL, R. (1997) Managing semantic heterogeneity in databases: a theoretical prospective. Proceedings of the sixteenth ACM SIGACT-SIGMOD-SIGART symposium on Principles of database systems. Arizona, United States ACM.

JHARKHARIA, S., SHANKAR, R. (2005) IT enablement of supply chains: modeling the enablers. International Journal of Productivity and Performance Management, 53, 700-712.

JUNG, J. (2008) Taxonomy alignment for interoperability between heterogeneous virtual organizations. Expert Systems with Applications, 34, 2721-2731.

JUNG, J., LEE, K.-S., PARK, S.-B. \& JO, G.-S. (2005) Efficient web browsing with semantic annotation: a case study of product images in e-commerce sites. IEICE Transactions on Information and Systems, E88-D, 843-850. 
JÜTTNER, U. (2005) Understanding the business requirements from a practitioner perspective. The International Journal of Logistics Management, 16, 120-141.

JÜTTNER, U., PECK, H. \& CHRISTOPHER, M. (2002) Supply chain risk management: outlining an agenda for future research. IN GRIFFITHS, J., HEWITT, F. \& IRLEAND, P. (Eds.) Proceedings of the Logistics Research Network 7th Annual Conference.

KANNAN, G., HAQ, A. N., SASIKUMAR, P. \& ARUNACHALAM, S. (2008) Analysis and selection of green suppliers using interpretative structural modelling and analytic hierarchy process. International Journal of Management and Decision Making, 9, 163-182.

KANTER, R. M. (1997) Restoring people to the heart of the organisation of the future. IN JOSSEY-BASS (Ed.) The Organisation of the Future. San Francisco.

LEE, H. L., PADMANABHAN, V. \& WANG, S. (1997) Information distortion in a supply chain: the bullwhip effect. Management Science, 43, 546-558.

LEMKEN, B., KAHLER, H. \& RITTENBRUCH, M. (2000) Sustained knowledge management by organizational culture. Proceedings of the 33rd Annual Hawaii International Conference on System Sciences. Germany, Institution of Computer Science, Bonn University.

LENGNICK-HALL, C. A. (1998) Customer contributions to quality: a different view of the customer-oriented firm. Academy of Management Review, 21, 791-824.

LEWICKI, R., MCALLISTER, D. \& BIES, R. (1998) Trust and Distrust: New Relationships and Realities. Academy of Management Review, 23, 438-458.

MANDAL, A., DESHMUKH, S.G. (1994) Vendor selection using interpretive structural modeling (ISM). International Journal of Operations \& Production Management, 14, 52-61.

MENTZER, J. T. (2001) Defining Supply Chain Management. Journal of Business logistics, $22,1-25$.

MISTRY, J. J. (2005) Origins of profitability through JIT processes in the supply chain. Industrial Management \& Data Systems, 105, 752-768.

NGUYEN, D., THOMPSON, S. G., PATEL, J., TEACY, L. W., JENNINGS, N. R., LUCK, M., DANG, V., CHALMERS, S., OREN, N., NORMAN, T. J., PREECE, A., GRAY, P. M., SHERCLIFF, G., STOCKREISSER, P. J., SHAO, J., GRAY, W. A. \& FIDDIAN, N. J. (2006) Delivering services by building and running virtual organisations BT Technology Journal 24, 141-152.

PANTELI, N. \& SOCKALINGAMB, S. (2005) Trust and conflict within virtual interorganizational alliances: a framework for facilitating knowledge sharing Decision Support Systems, 39, 599-617.

PASCALE, R. T. (1994) Intentional breakdowns and conflict by design. Planning Review, $22,12-16$.

PLISSON, J., LJUBIC, P., MOZETIC, I. \& LAVRAC, N. (2007) An Ontology for Virtual Organization Breeding Environments. IEEE Transactions on Systems, Man, and Cybernetics, Part C 37, 1327-1341.

PORTER, M. E. (1998) Clusters and the new economics of competition. Harvard Business Review, November-December, 77-90.

PRATER, E., BIEHL, M. \& SMITH, M. A. (2001) International supply chain agility. International Journal of Operations \& Production Management, 21, 823-839.

PREFONTAINE, L. (2003) Risk Management in New Models of Collaboration in New Models of Collaboration: A Guide for Managers.

QUIRCHMAYR, G., MILOSEVIC, Z., TAGG, R., COLE, J. B. \& KULKARNI, S. (2002) Establishment of Virtual Enterprise Contracts. Proceedings of the 13th International 
Conference on Database and Expert Systems Applications Berlin, Springer

RAHMAN, Z. (2004) Use of internet in supply chain management: a study of Indian companies. Industrial Management \& Data Systems, 104, 31-41.

RAVI, V., SHANKAR, R (2005) Analysis of interactions among the barriers of reverse logistics. Technological Forecasting and Social Changes, 72, 1011-1029.

RITCHIE, B. \& BRINDLEY, C. ( 2002) Reassessing the management of the global supply chain. Integrated Manufacturing Systems, 13, 110-116.

RYUTOV, T., NEUMAN, C., ZHOU, L. \& FOUKIA, N. (2007) Initial trust formation in Virtual Organisations. International Journal of Internet Technology and Secured Transactions, 1.

SAATY, T. L. (2001) Decision-making with Dependence and Feedback: The Analytic Network Processes, Pittsburgh, RWS Publications.

SAGE, A. P. (1977.) Interpretive Structural Modeling: Methodology for Large-scale Systems, New York, NY, McGraw-Hill.

SAHAY, B. S. \& MAINI, A. (2002) Supply chain: a shift from transactional to collaborative partnership. Decision, 29, 67-88.

SARI, B., AMAITIK, S. \& KILIC, S. E. (2007) A neural network model for the assessment of partners? performance in virtual enterprises. The International Journal of Advanced Manufacturing Technology, 34, 816-825.

SHTUB, A., BARD, J. F. \& GLOBERSON, S. (1994) Project Management: Engineering, Technology and Implementation, Englewood Cliffs, NJ, Prentice-Hall.

SINGH, M. D. \& KANT, R. (2008) Knowledge management barriers: An interpretive structural modeling approach. International Journal of Management Science and Engineering Management, 3, 141-150.

SINHA, P. R., WHITMAN, L. E. \& MALZAHN, D. (2004) Methodology to mitigate supplier risk in an aerospace supply chain. Supply Chain Management: An International Journal, 9, 154-168.

SPECKMAN, R. E. \& DAVIS, E. W. (2004) Risky business: expanding the discussion on risk and the extended enterprise. International Journal of Physical Distribution \& Logistics management, 34, 414.

Susman, G. L., Gray, B. L., Perry, J. and Blair, C. E. (2003) 'Recognition and Reconcilation of Differences in Interpretation of Misalignments When Collaborative Technologies Are Introduced into New Product Development Teams.' Journal of Engineering and Technology Management 20, (1-2) 141-159

The international Virtual laboratory for Enterprise Interoperability. Source [online]. Available from http://interop-vlab.eu/ [accessed 9 November 2009].

TSAY, A. A. (1999) The Quantity Flexibility Contract and Supplier-Customer Incentives Source Management Science archive, 45, 1339-1358.

TWOMEY, D. (1995) Inter-organizational conflict resolution: the effects of power and trust. Academy of Management Proceedings.

WALLER, R. J. (1975) Application of interpretive structural modeling to priority-setting in urban systems management. In BALDWIN, M. (Ed.) Portraits of complexity. Columbus, $\mathrm{OH}$, Battelle Memorial Institute.

WARFIELD, J. (1974.) Developing Interconnected Matrices in Structural Modelling. IEEE Transactions on Systems Men and Cybernetics, 4, 51-81.

WARFIELD, J. (1990) A science of generic design; Managing complexity through systems design, CA, Salinas.

WARNFIELD, J. (2005) Developing interconnection matrices in structural modeling. IEEE Transactions on systems, Man and cybernetics, 4, 67-81.

WESTPHAL, I., THOBEN, K.-D. \& SEIFERT, M. (2007) Measuring Collaboration 
Performance In Virtual Organizations. Establishing The Foundation Of Collaborative Networks. Guimarães, Springer Boston.

WILMOT, W. W. \& HOCKER, J. L. (2001) Interpersonal conflict, New York, McGrawHill.

Wong, E. T. T. (2009) 'Trust Management in Virtual Product Development Networks.' In Encyclopedia of Information Science and Technology, Second Edition. ed. by Khosrow-Pour, M. Hershey, USA: IGI Global: 3831-3839

YOU, T.-H., ZHU, Z. \& YU, Z.-C. (2006 ) Analysis and Assessment of Knowledge Sharing Risk in the Virtual Enterprise. JCIS-2006 Proceedings

YU, Z., YAN, H. \& CHENG, T. C. E. (2001.) Benefits of information sharing with supply chain partnerships. Industrial Management \& Data Systems, 101, 114-121.

ZAHEER, A., MCEVILY, B. \& PERRONE, V. (1998) Does trust matter? Exploring the effects of interorganizational and interpersonal trust on performance. Organization Science, 9, 141-159.

ZHANG, Y. \& DILTS, D. (2004) System dynamic of supply chain network organization structure. Information Systems and E-Business Management, 2, 187-206.

ZHENG, J., JOHNSEN, T., HARLAND, C. M. \& LAMMING, R. C. (1998) Initial conceptual framework for creation and operation of supply networks. Proceedings of the 14th IMP Annual Conference. Turku.

ZHENXIN, Y., YAN, H. \& CHENG, T. C. (2001) Benefits of information sharing with supply chain partnerships. Industrial Management \& Data Systems, 101, 114-120. 
Table 1. Summary of the questionnaire.

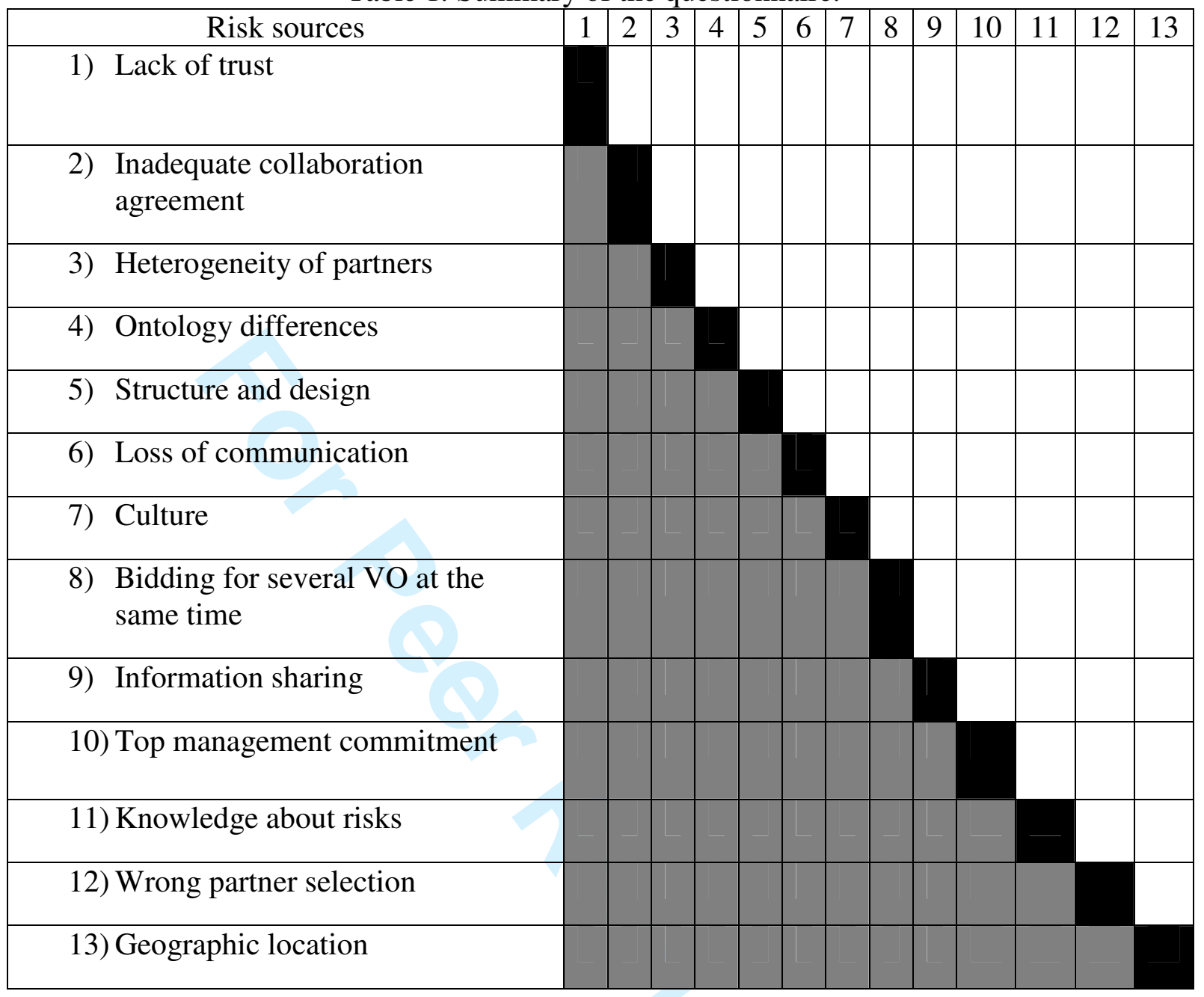

Contextual relationship $=$ leads to

What to enter in the white cells

Enter $\mathbf{V}$ when the row influences the column

Enter $\mathbf{A}$ when the column influences the row

Enter $\mathbf{O}$ when there is no relation between the row and the column

Enter $\mathbf{X}$ when row and column influences each other 
Table 2. Structural self-interaction matrix (SSIM).

\begin{tabular}{|c|c|c|c|c|c|c|c|c|c|c|c|c|c|}
\hline Risk sources & 1 & 2 & 3 & 4 & 5 & 6 & 7 & 8 & 9 & 10 & 11 & 12 & 13 \\
\hline 1. Lack of trust between partners & & $\mathrm{A}$ & A & $\mathrm{A}$ & A & A & $\mathrm{A}$ & $\mathrm{V}$ & $\mathrm{X}$ & $\mathrm{X}$ & $\mathrm{O}$ & $\mathrm{V}$ & $\mathrm{A}$ \\
\hline $\begin{array}{l}\text { 2. Inadequate collaboration } \\
\text { agreement }\end{array}$ & $\mathrm{V}$ & 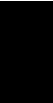 & $\mathrm{O}$ & $\mathrm{A}$ & $\mathrm{O}$ & $\mathrm{V}$ & $\mathrm{O}$ & $\mathrm{V}$ & $\mathrm{V}$ & $\mathrm{V}$ & $\mathrm{V}$ & $\mathrm{V}$ & $\mathrm{O}$ \\
\hline 3. Heterogeneity of partners & V & $\mathrm{O}$ & 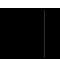 & $\mathrm{O}$ & V & $\mathrm{V}$ & $\mathrm{O}$ & $\mathrm{V}$ & $\mathrm{V}$ & $\mathrm{V}$ & $\mathrm{V}$ & $\mathrm{V}$ & $\mathrm{O}$ \\
\hline 4. Ontology differences & $\mathrm{V}$ & $\mathrm{V}$ & $\mathrm{O}$ & & $\mathrm{O}$ & $\mathrm{V}$ & $\mathrm{O}$ & $\mathrm{V}$ & $\mathrm{V}$ & $\mathrm{V}$ & $\mathrm{V}$ & $\mathrm{V}$ & $\mathrm{O}$ \\
\hline 5. Structure and design & $\mathrm{V}$ & $\mathrm{O}$ & $\mathrm{A}$ & $\mathrm{O}$ & $\ldots$ & $\mathrm{V}$ & $\mathrm{O}$ & $\mathrm{V}$ & $\mathrm{V}$ & $\mathrm{V}$ & $\mathrm{V}$ & $\mathrm{V}$ & $\mathrm{O}$ \\
\hline 6. Loss of communication & $\mathrm{V}$ & $\mathrm{A}$ & $\mathrm{A}$ & A & A & 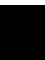 & $\mathrm{A}$ & $\mathrm{V}$ & $\mathrm{V}$ & $\mathrm{V}$ & $\mathrm{V}$ & $\mathrm{V}$ & $\mathrm{A}$ \\
\hline 7. Culture differences & $\mathrm{V}$ & $\mathrm{O}$ & $\mathrm{O}$ & $\mathrm{O}$ & $\mathrm{O}$ & V & & $\mathrm{V}$ & $\mathrm{V}$ & $\mathrm{V}$ & $\mathrm{V}$ & $\mathrm{V}$ & $\mathrm{O}$ \\
\hline $\begin{array}{l}\text { 8. Bidding for several } \mathrm{VO} \text { at the } \\
\text { same time }\end{array}$ & $\mathrm{A}$ & $\mathrm{A}$ & $\mathrm{A}$ & A & $\mathrm{A}$ & $\mathrm{A}$ & A & 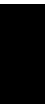 & $\mathrm{O}$ & $\mathrm{A}$ & $\mathrm{V}$ & $\mathrm{V}$ & $\mathrm{A}$ \\
\hline 9. Lack of information sharing & $\mathrm{X}$ & $\mathrm{A}$ & $\mathrm{A}$ & A & A & $\mathrm{A}$ & A & $\mathrm{O}$ & . & $\mathrm{X}$ & $\mathrm{V}$ & $\mathrm{V}$ & A \\
\hline $\begin{array}{l}\text { 10. Lack of top management } \\
\text { commitment }\end{array}$ & $\mathrm{X}$ & $\mathrm{A}$ & $\mathrm{A}$ & A & $\mathrm{A}$ & A & $\mathrm{A}$ & $\mathrm{V}$ & $\mathrm{X}$ & & $\mathrm{O}$ & $\mathrm{V}$ & A \\
\hline 11. Lack of knowledge about risks & $\mathrm{O}$ & $\mathrm{A}$ & $\mathrm{A}$ & A & $\overline{\mathrm{A}}$ & $\mathrm{A}$ & $\mathrm{A}$ & $\bar{A}$ & $\mathrm{~A}$ & $\mathrm{O}$ & & $\mathrm{V}$ & $\mathrm{A}$ \\
\hline 12. Wrong partner/s selection & A & A & A & A & A & A & A & A & $\mathrm{A}$ & A & A & & A \\
\hline 13. Geographic location & $\mathrm{V}$ & $\mathrm{O}$ & $\mathrm{O}$ & $\mathrm{O}$ & $\mathrm{O}$ & $\bar{V}$ & $\mathrm{O}$ & $\bar{V}$ & $\mathrm{~V}$ & $\mathrm{~V}$ & $\mathrm{~V}$ & $\mathrm{~V}$ & \\
\hline
\end{tabular}


Table 3. Reachability matrix table.

\begin{tabular}{|c|c|c|c|c|c|c|c|c|c|c|c|c|c|c|}
\hline Risk source & 1 & 2 & 3 & 4 & 5 & 6 & 7 & 8 & 9 & 10 & 11 & 12 & 13 & Driver \\
\hline 1. Lack of trust between partners & 1 & 0 & 0 & 0 & 0 & 0 & 0 & 1 & 1 & 1 & 0 & 1 & 0 & 5 \\
\hline $\begin{array}{l}\text { 2. Inadequate collaboration } \\
\text { agreement }\end{array}$ & 1 & 1 & 0 & 0 & 0 & 1 & 0 & 1 & 1 & 1 & 1 & 1 & 0 & 8 \\
\hline 3. Heterogeneity of partners & 1 & 0 & 1 & 0 & 1 & 1 & 0 & 1 & 1 & 1 & 1 & 1 & 0 & 9 \\
\hline 4. Ontology differences & 1 & 1 & 0 & 1 & 0 & 1 & 0 & 1 & 1 & 1 & 1 & 1 & 0 & 9 \\
\hline 5. $\quad$ Structure and design & 1 & 0 & 0 & 0 & 1 & 1 & 0 & 1 & 1 & 1 & 1 & 1 & 0 & 8 \\
\hline 6. Loss of communication & 1 & 0 & 0 & 0 & 0 & 1 & 0 & 1 & 1 & 1 & 1 & 1 & 0 & 7 \\
\hline 7. Culture & 1 & 0 & 0 & 0 & 0 & 1 & 1 & 1 & 1 & 1 & 1 & 1 & 0 & 8 \\
\hline $\begin{array}{l}\text { 8. Bidding for several } \mathrm{VO} \text { at the } \\
\text { same time }\end{array}$ & 0 & 0 & 0 & 0 & 0 & 0 & 0 & 1 & 0 & 0 & 1 & 1 & 0 & 3 \\
\hline $\begin{array}{l}\text { 9. Information sharing between } \\
\text { partners }\end{array}$ & 1 & 0 & 0 & 0 & $\overline{0}$ & $\overline{0}$ & 0 & 0 & 1 & 1 & 1 & 1 & 0 & 5 \\
\hline $\begin{array}{l}\text { 10. Lack of top management } \\
\text { commitment }\end{array}$ & 1 & 0 & 0 & 0 & 0 & 0 & 0 & 1 & 1 & 1 & 0 & 1 & 0 & 5 \\
\hline 11. Knowledge about risks & 0 & 0 & 0 & 0 & 0 & 0 & 0 & 0 & 0 & 0 & 1 & 1 & 0 & 2 \\
\hline 12. Wrong partner/s selection & 0 & 0 & 0 & 0 & 0 & 0 & 0 & 0 & 0 & 0 & 0 & 1 & 0 & 1 \\
\hline 13. Geographic location & 1 & 0 & 0 & 0 & 0 & 1 & 0 & 1 & 1 & 1 & 1 & 1 & 1 & 8 \\
\hline Dependence & 10 & 2 & 1 & 1 & 2 & 7 & 1 & 10 & 10 & 10 & 10 & 13 & 1 & \\
\hline
\end{tabular}


Table 4. Iteration 1

\begin{tabular}{|c|c|c|c|c|}
\hline Risk source & Reachability set & Antecedent set & $\begin{array}{l}\text { Intersection } \\
\text { set }\end{array}$ & Level \\
\hline $\begin{array}{l}\text { 1. Lack of trust between } \\
\text { partners }\end{array}$ & $1,8,9,10,12$ & $1,2,3,4,5,6,7,9,10,13$ & $1,9,10$ & - \\
\hline $\begin{array}{l}\text { 2. Inadequate collaboration } \\
\text { agreement }\end{array}$ & $1,2,6,8,9,10,11,12$ & 2,4 & 2 & - \\
\hline 3. Heterogeneity of partners & $1,3,5,6,8,9,10,11,12$ & 3 & 3 & - \\
\hline 4. Ontology differences & $1,2,4,6,8,9,10,11,12$ & 4 & 4 & - \\
\hline 5. $\quad$ Structure and design & $1,5,6,8,9,10,11,12$ & 3,5 & 5 & - \\
\hline 6. Loss of communication & $1,6,8,9,10,11,12$ & $2,3,4,5,6,7,13$ & 6 & - \\
\hline 7. Culture differences & $1,6,7,8,9,10,11,12$ & 7 & 7 & - \\
\hline $\begin{array}{l}\text { 8. Bidding for several VO at } \\
\text { the same time }\end{array}$ & $8,11,12$ & $1,2,3,4,5,6,7,8,10,13$ & 8 & - \\
\hline $\begin{array}{l}\text { 9. Lack of information } \\
\text { sharing }\end{array}$ & $1,9,10,11,12$ & $1,2,3,4,5,6,7,9,10,13$ & $1,9,10$ & - \\
\hline $\begin{array}{l}\text { 10. Lack of top management } \\
\text { commitment }\end{array}$ & $1,8,9,10,12$ & $1,2,3,4,5,6,7,9,10,13$ & $1,9,10$ & - \\
\hline $\begin{array}{l}\text { 11. Lack of knowledge about } \\
\text { risks }\end{array}$ & 11,12 & $2,3,4,5,6,7,8,9,11,13$ & 11 & - \\
\hline 12. Wrong partner/s selection & 12 & $\begin{array}{l}1,2,3,4,5,6,7,8,9,10 \\
11,12,13\end{array}$ & 12 & 1 \\
\hline 13. Geographic location & $1,6,8,9,10,11,12,13$ & 13 & 13 & - \\
\hline
\end{tabular}

Table 5. Iteration 2

\begin{tabular}{|l|l|l|l|l|}
\hline Risk source & $\begin{array}{l}\text { Reachability } \\
\text { set }\end{array}$ & Antecedent set & $\begin{array}{l}\text { Intersection } \\
\text { set }\end{array}$ & Level \\
\hline $\begin{array}{l}\text { 1. } \\
\text { Lack of trust between }\end{array}$ & $1,8,9,10$ & $1,2,3,4,5,6,7,9,10,13$ & $1,9,10$ & - \\
\hline $\begin{array}{l}\text { partners } \\
\text { Inadequate collaboration } \\
\text { agreement }\end{array}$ & $1,2,6,8,9,10,11$ & 2,4 & 2 & - \\
\hline 3. Heterogeneity of partners & $1,3,5,6,8,9,10,11$ & 3 & 3 & - \\
\hline 4. Ontology differences & $1,2,4,6,8,9,10,11$ & 4 & 4 & - \\
\hline 5. Structure and design & $1,5,6,8,9,10,11$ & 3,5 & 5 & - \\
\hline 6. $\quad$ Loss of communication & $1,6,8,9,10,11$ & $2,3,4,5,6,7,13$ & 6 & - \\
\hline
\end{tabular}




\begin{tabular}{|l|l|l|l|l|}
\hline 7. Culture differences & $1,6,7,8,9,10,11$ & 7 & 7 & - \\
\hline $\begin{array}{l}\text { 8. } \\
\text { Bidding for several VO at } \\
\text { the same time }\end{array}$ & 8,11 & $1,2,3,4,5,6,7,8,10,13$ & 8 & - \\
\hline 9. Lack of information sharing & $1,9,10,11$ & $1,2,3,4,5,6,7,9,10,13$ & $1,9,10$ & - \\
\hline $\begin{array}{l}\text { 10. Lack of top management } \\
\text { commitment }\end{array}$ & $1,8,9,10$ & $1,2,3,4,5,6,7,9,10,13$ & $1,9,10$ & - \\
\hline $\begin{array}{l}\text { 11. Lack of knowledge about } \\
\text { risks }\end{array}$ & 11 & $2,3,4,5,6,7,8,9,11,13$ & 11 & 2 \\
\hline \begin{tabular}{l} 
13. Geographic location \\
\hline
\end{tabular} & $1,6,8,9,10,11,13$ & 13 & 13 & - \\
\hline
\end{tabular}

Table 6, Iteration 3

\begin{tabular}{|c|c|c|c|c|}
\hline Risk source & $\begin{array}{l}\text { Reachability } \\
\text { set }\end{array}$ & Antecedent set & $\begin{array}{l}\text { Intersection } \\
\text { set }\end{array}$ & Level \\
\hline $\begin{array}{l}\text { 1. Lack of trust between } \\
\text { partners }\end{array}$ & $1,8,9,10$ & $1,2,3,4,5,6,7,9,10,13$ & $1,9,10$ & - \\
\hline $\begin{array}{l}\text { 2. Inadequate collaboration } \\
\text { agreement }\end{array}$ & $1,2,6,8,9,10$ & 2,4 & 2 & - \\
\hline 3. Heterogeneity of partners & $1,3,5,6,8,9,10$ & 3 & 3 & - \\
\hline 4. Ontology differences & $1,2,4,6,8,9,10$ & 4 & 4 & - \\
\hline 5. Structure and design & $1,5,6,8,9,10$ & 3,5 & 5 & - \\
\hline 6. Loss of communication & $1,6,8,9,10$ & $2,3,4,5,6,7,13$ & 6 & - \\
\hline 7. Culture differences & $1,6,7,8,9,10$ & 7 & 7 & - \\
\hline $\begin{array}{l}\text { 8. Bidding for several VO at the } \\
\text { same time }\end{array}$ & 8 & $1,2,3,4,5,6,7,8,10,13$ & 8 & 3 \\
\hline 9. Lack of information sharing & $1,9,10$ & $1,2,3,4,5,6,7,9,10,13$ & $1,9,10$ & 3 \\
\hline $\begin{array}{l}\text { 10. Lack of top management } \\
\text { commitment }\end{array}$ & $1,8,9,10$ & $1,2,3,4,5,6,7,9,10,13$ & $1,9,10$ & - \\
\hline 13. Geographic location & $1,6,8,9,10,13$ & 13 & 13 & - \\
\hline
\end{tabular}


Table 7, Iteration 4

\begin{tabular}{|l|l|l|l|l|}
\hline Risk source & $\begin{array}{l}\text { Reachability } \\
\text { set }\end{array}$ & Antecedent set & $\begin{array}{l}\text { Intersection } \\
\text { set }\end{array}$ & Level \\
\hline 1. Lack of trust between partners & 1,10 & $1,2,3,4,5,6,7,10,13$ & 1,10 & 4 \\
\hline $\begin{array}{l}\text { 2. Inadequate collaboration } \\
\text { agreement }\end{array}$ & $1,2,6,10$ & 2,4 & 2 & - \\
\hline 3. Heterogeneity of partners & $1,3,5,6,10$ & 3 & 3 & - \\
\hline 4. Ontology differences & $1,2,4,6,10$ & 4 & 4 & - \\
\hline 5. Structure and design & $1,5,6,10$ & 3,5 & 5 & - \\
\hline $\begin{array}{l}\text { 6. Loss of communication } \\
\text { 7. Culture differences }\end{array}$ & $1,6,10$ & $2,3,4,5,6,7,13$ & 6 & - \\
\hline $\begin{array}{l}\text { 10. Lack of top management } \\
\text { commitment }\end{array}$ & $1,6,7,10$ & 7 & 7 & - \\
\hline 13. Geographic location & $1,6,10,13$ & 13 & $1,2,3,4,5,6,7,10,13$ & 1,10 \\
\hline
\end{tabular}

Table 8, Iteration 5

\begin{tabular}{|l|l|l|l|l|}
\hline Risk source & $\begin{array}{l}\text { Reachability } \\
\text { set }\end{array}$ & $\begin{array}{l}\text { Antecedent } \\
\text { set }\end{array}$ & $\begin{array}{l}\text { Intersection } \\
\text { set }\end{array}$ & Level \\
\hline $\begin{array}{l}\text { 2. Inadequate collaboration } \\
\text { agreement }\end{array}$ & 2,6 & 2,4 & 2 & - \\
\hline 3. Heterogeneity of partners & $3,5,6$ & 3 & 3 & - \\
\hline 4. Ontology differences & $2,4,6$ & 4 & 4 & - \\
\hline 5. Structure and design & 5,6, & 3,5 & 5 & - \\
\hline 6. Loss of communication & 6 & $2,3,4,5,6,7,13$ & 6 & 5 \\
\hline 7. $\quad$ Culture differences & 6,7 & 7 & 7 & - \\
\hline 13. Geographic location & 6,13 & 13 & 13 & - \\
\hline
\end{tabular}




\begin{tabular}{|l|l|l|l|l|}
\hline Risk source & $\begin{array}{l}\text { Reachability } \\
\text { set }\end{array}$ & $\begin{array}{l}\text { Antecedent } \\
\text { set }\end{array}$ & $\begin{array}{l}\text { Intersection } \\
\text { set }\end{array}$ & Level \\
\hline $\begin{array}{l}\text { 2. Inadequate collaboration } \\
\text { agreement }\end{array}$ & 2 & 2,4 & 2 & 6 \\
\hline 3. Heterogeneity of partners & 3,5 & 3 & 3 & - \\
\hline 4. Ontology differences & 2,4 & 4 & 4 & - \\
\hline 5. Structure and design & 5 & 3,5 & 5 & 6 \\
\hline 7. Culture differences & 7 & 7 & 7 & 6 \\
\hline 13. Geographic location & 13 & 13 & 13 & 6 \\
\hline
\end{tabular}

Table 10, Iteration 7

\begin{tabular}{|l|l|l|l|l|}
\hline Risk source & Reachability set & Antecedent set & Intersection set & Level \\
\hline 3. Heterogeneity of partners & 3 & 3 & 3 & 7 \\
\hline 4. Ontology differences & 4 & 4 & 4 & 7 \\
\hline
\end{tabular}


Figure 1. Flow diagram for preparing ISM.

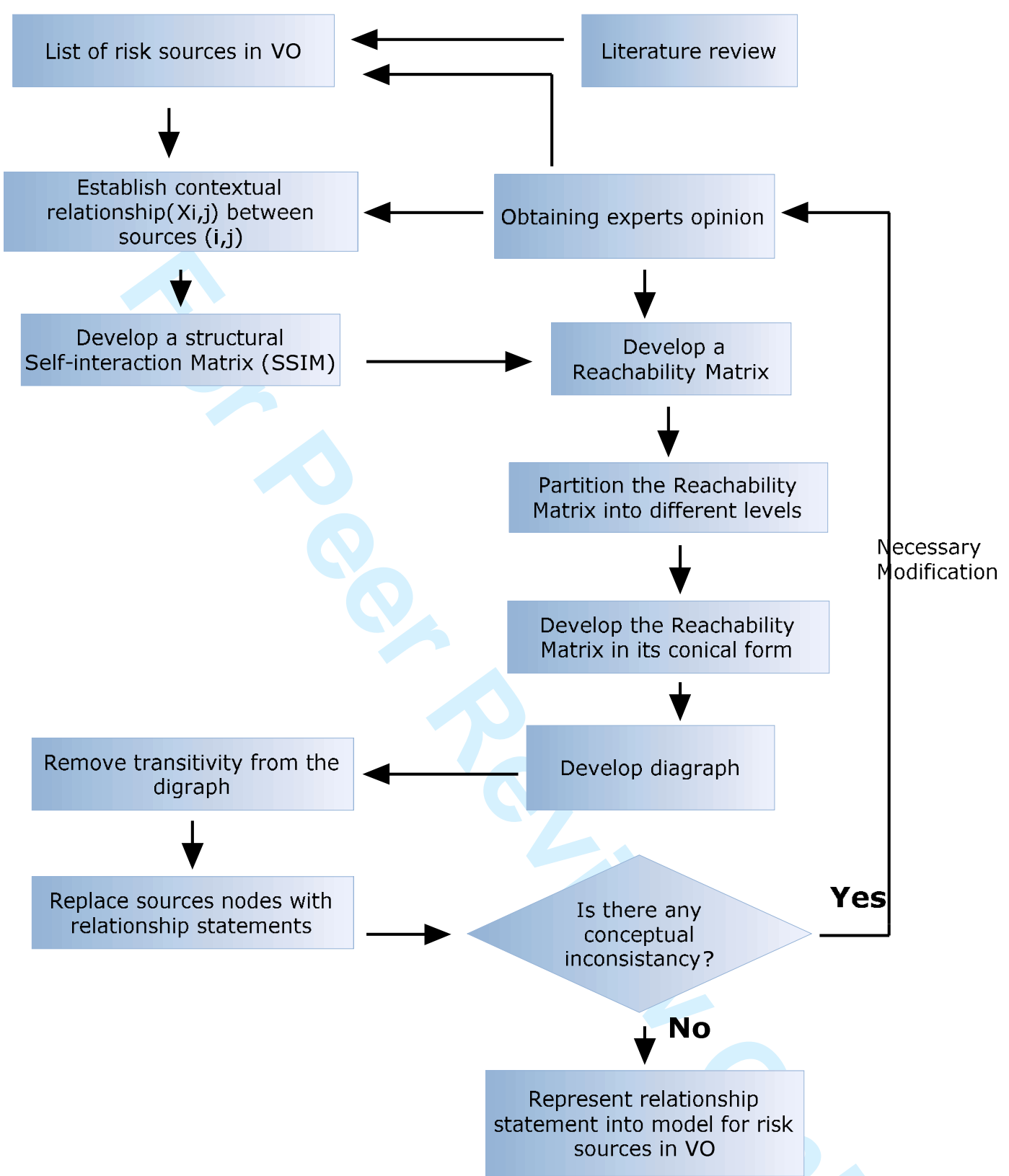


Figure 2. ISM model.

Wrong partner/s selection

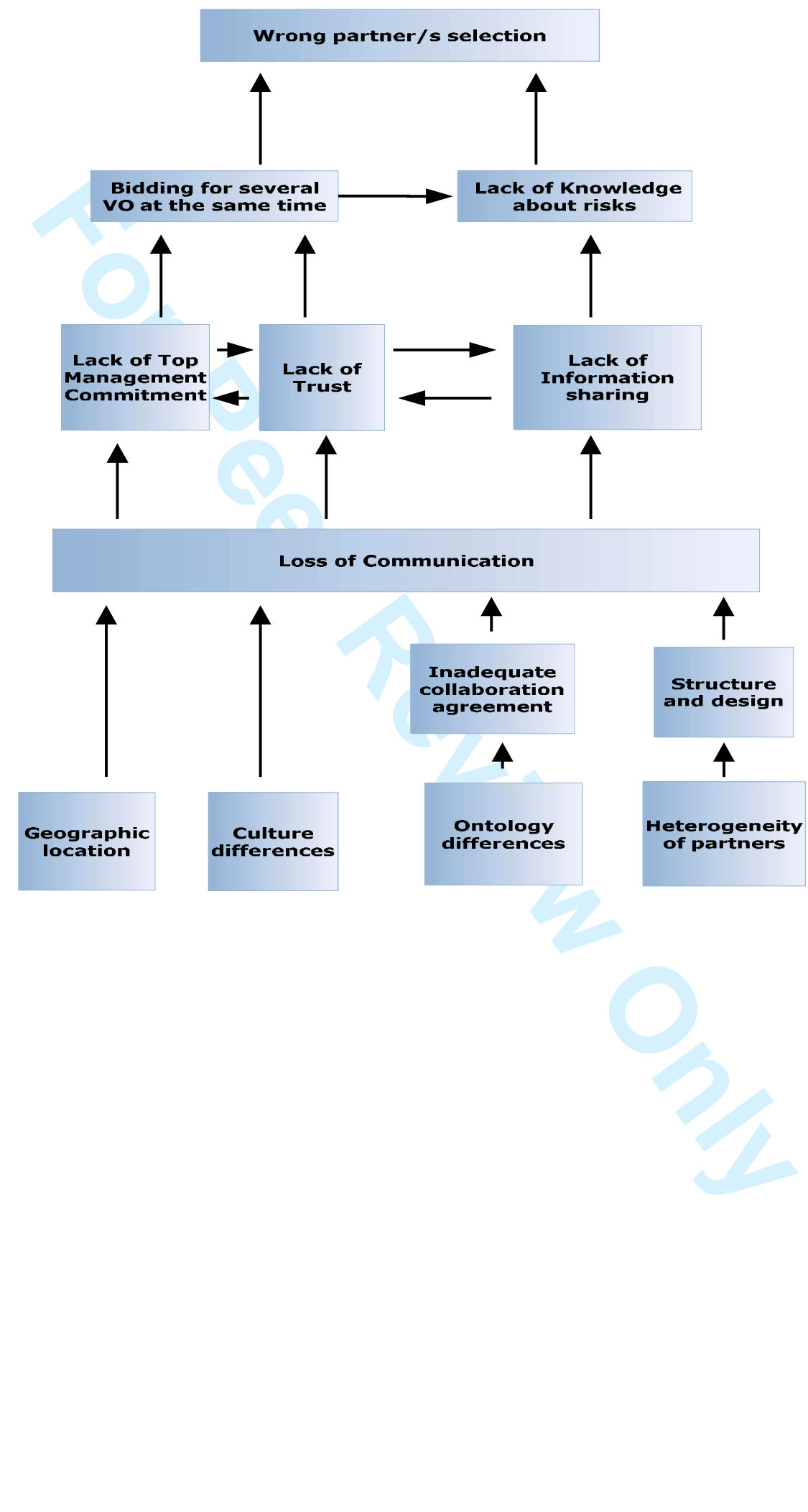


Figure 3. Driver power-dependence diagram.

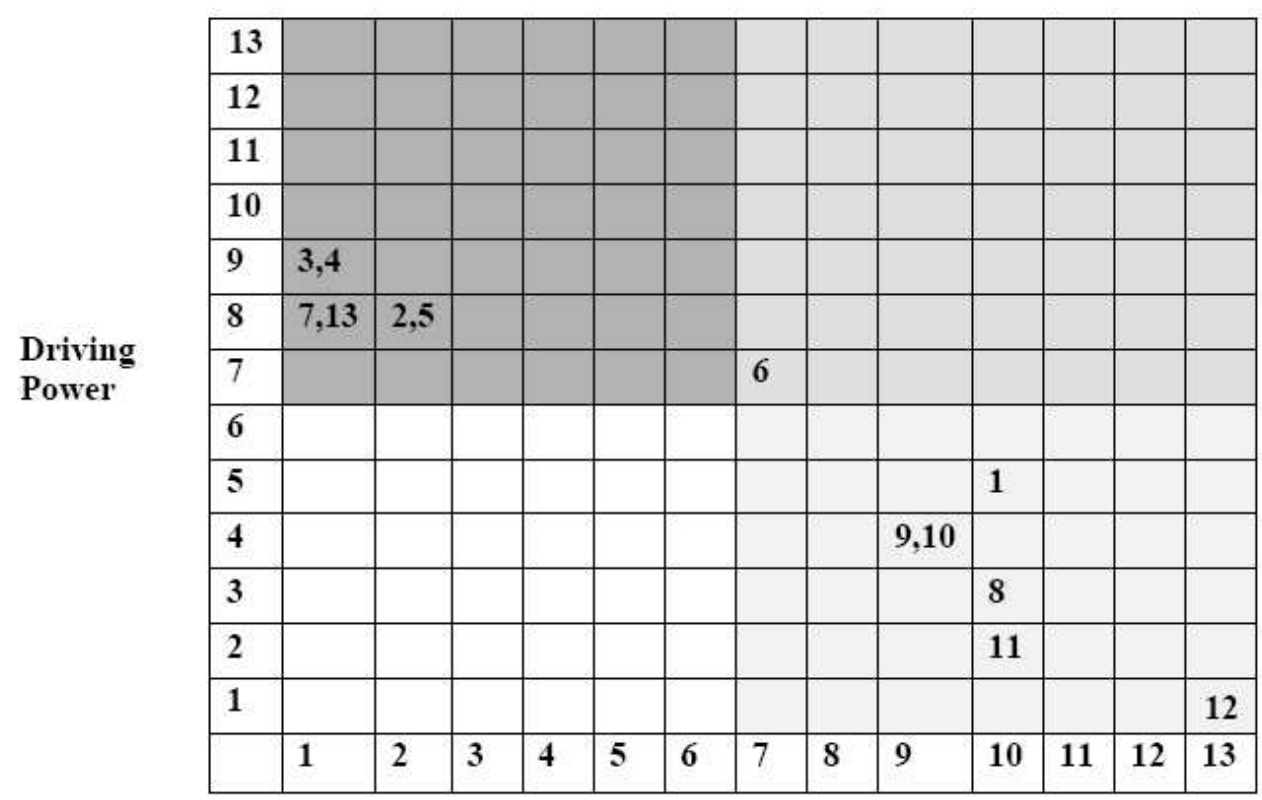

Dependence power 